\title{
Ilustracje Stanisława Haykowskiego w powieści Ferdynanda Ossendowskiego Pod sztandarami Sobieskiego
}

Wojciech Gorczyca (Polsko)

\begin{abstract}
Abstrakt
W dyskursie literackim Ferdynanda Ossendowskiego autor odnotowuje obecność porządku lokalnego (mieszkańcy Karpat Wschodnich) i globalnego (naród), co łączy się z przyznaniem kluczowej roli dyskursowi tożsamości. Tożsamość zbiorowa jest dla Ossendowskiego tożsamością szlachecką. Tworzy ją szlachta bezherbowa, walcząc u boku swego króla pod Żurawnem (1676 r.). Historiozofia Ossendowskiego w powieści Pod sztandarami Sobieskiego nakierowana jest na otwieranie drzwi ku teraźniejszości i wyznaczanie perspektyw przyszłości. W odróżnieniu od Henryka Sienkiewicza (Trylogia, 1883-1888) Ossendowski nie pisze powieści przede wszystkim dla „pokrzepienia serc”.

Stanisław Haykowski jest autorem trzech ilustracji do powieści Ossendowskiego, spośród których autor analizuje dwie. Haykowski tworzy ilustrację interpretacyjną, ekspresywną - do pewnego stopnia autoteliczną. Jako malarz batalista modyfikuje niektóre sceny zdarzeń stworzone przez Ossendowskiego. Operuje światłem, cieniem i półcieniem w kreowaniu świata wewnętrznego postaci. Jest przy tym mistrzem aktorstwa ciała - ciała rycerza.
\end{abstract}

\section{Słowa klucze}

porządek lokalny i globalny; dyskurs tożsamości; tożsamość zbiorowa; ilustracja interpretacyjna; ekspresywna; aktorstwo ciała

\section{Abstract \\ Stanislav Haykovsky's Illustrations in the Ferdinand Ossendovsky's Novel Under the Banner of Sobieski}

In Ferdinand Ossendovsky's literary discourse the author notices the presence of local (inhabitants of the Eastern Carpathians) and global (nation) order, which combines with assigning a primary role to identity discourse. Collective identity for Ossendovsky is the noble identity. It is formed by non-arms nobility, fighting alongside their king by Żurawno (1676). Ossendovsky's historiosophy in the novel Under the banner of Sobieski is aimed at opening the doors to the present and designating perspectives of the future. Contrary to Henryk Sienkiewicz (The Trilogy, 1883-1888), Ossendovsky does not write a novel mostly to 'comfort hearts'.

Stanislav Haykovsky is the author of three illustrations for the Ossendovsky's novel, two of which are analysed by the author. Haykovsky creates interpretative, expressive illustration - to some extend also autotelic. As a battle painter, Haykovsky modifies some of the scenes created by Ossendovsky. He controls light, shade, halfshade in creating an inner world of a character. Haykovsky is also a master of body acting, the body of the knight.

\section{Key words}

local and global order; identity discourse; collective identity; interpretative illustration; expressive illustration; body acting 
Stanisława Haykowskiego (1902-1943), znanego i uznanego [w latach 30. XX wieku uzup. W. G.], jak pisze o nim Władysław Bartoszewski ${ }^{1}$, polskiego malarza batalistę, kierownika prac i autora szaty graficznej Ksiegi Jazdy Polskiej², wyróżnia spośród innych malarzy batalistów polskich aspekt doświadczeniowy. Haykowski jako ochotnik walczył w elitarnym 1. Pułku Ułanów Krechowieckich w wojnie polsko-bolszewickiej (1919-1921) oraz w 6. Pułku Strzelców Konnych im. Hetmana Wielkiego Koronnego Stanisława Żółkiewskiego ${ }^{3}$. Wiąże się to m.in. z umiejętnością trafnego przedstawienia frapującej giętkości i umiejętności dopasowywania się jeźdźca do konia we wszystkich sytuacjach. Sztuka Haykowskiego, jakkolwiek mieści się w kanonach malarstwa realistycznego (też dokumentalnego), to korzysta także z ustaleń poetyki neoklasycyzmu. Interesuja go trzy kryteria: ładność, piękno i rozum. Gestu oratorskiego u niego nie spotykamy ${ }^{4}$.

Swoje umiejętności Haykowski doskonalił, ilustrując m.in. powieści historyczne. W 1938 roku ukazała się powieść Ferdynanda Antoniego Ossendowskiego ${ }^{5}$ pt. Pod sztandarami Sobieskiego. Haykowskiego uważa się za współautora tej powieści. Zamieścił w niej trzy ilustracje (w artykule będę analizować dwie). Stanowią one, według mnie, apogeum jego talentu, ponadto ujawniają, nieśmiało zapowiadane wcześniej, tendencje do odkrywania świata wewnętrznego postaci, do pełnej symbolizacji zdarzeń i przedmiotów, współkreujących ów świat.

Podkreślę już na wstępie, że ilustracja Haykowskiego jest ilustracją interpretacyjną, ekspresywną. Aspiruje do kreowania estetycznych i psychologicznych znaczeń, jest wyrazem poszukiwania autoteliczności wobec uznania, iż tekst nie w pełni oddaje dramatyzm sytuacji i postaci ${ }^{6}$.

Dlaczego Stanisław Haykowski zdecydował się ilustrować tekst powieści Ossendowskiego Pod sztandarami Sobieskiego? Sa, według mnie, tego trzy przyczyny. Pierwsza wiąże się z faktem, że powieść jest pewnym sposobem obrachunku z przeszłością i udziela pew-

1 BARTOSZEWSKI, Władysław: Straceni na ulicach miasta. Warszawa: Książka i Wiedza, 1970, s. 44-55.

2 Por. Ksiega Jazdy Polskiej. Kierownictwo i opracowanie Stanisław Haykowski. Warszawa, 1938.

3 GORCZYCA, Wojciech: Stanistaw Haykowski (1902-1943). Utan i malarz batalista. Bielsko-Biała: Wydawnictwo Naukowe Akademii Techniczno-Humanistycznej, 2018, s. 38.

4 Ibidem, s. 56.

5 Ferdynand Ossendowski (1878-1945) studiował nauki matematyczno-przyrodnicze w Petersburgu. Wzią wówczas udział w wyprawach naukowych na Kaukaz, nad Dniestr, Jenisej, w okolice Bajkału. Dotarł również do Chin, Japonii, na Sumatrę i do Indii. Znał biegle 7 języków obcych. W 1899 roku musiał opuścić Rosję. Wyjechał do Paryża. Tutaj studiował fizykę i chemię na Sorbonie. Tutaj też miał okazję poznać Marię Curie-Skłodowską. W 1918 roku wrócił do Rosji. W czasie wojny domowej współpracował z dowództwem Białych. Sławę przyniosła mu książka Zwierzęta, ludzie, bogowie, w której zawarł swoje wspomnienia o Rosji ogarniętej chaosem rewolucji. Książka była wydawana w latach 1921-1923 w Nowym Jorku, Londynie i Warszawie. W latach międzywojennych nakład jego książek tłumaczonych na 20 języków obcych wyniósł $80 \mathrm{mln}$ egzemplarzy. Ossendowski zajmował wówczas drugie miejsce po Henryku Sienkiewiczu. Do 1990 roku twórczość literacka Ferdynada Ossendowskiego pozostawała w Polsce na indeksie. Por.: Ferdynand Ossendowski https://pl.wikipedia.org/wiki/Ferdynand_Ossendowski.

6 RUTKIEWICZ, Ewa: Wokót problemów ilustracji. http://www.ebib.pl/2010/118/a.php?rutkiewicz. W tym sensie jest to ilustracja inna aniżeli ilustracja Juliusza Kossaka, jaką identyfikujemy w Trylogii Henryka Sienkiewicza. Ilustrację Kossaka można nazwać odzwierciedlającą. 
nych wskazówek dla teraźniejszości i przyszłości . Ossendowski nie pisał tej powieści „dla pokrzepienia serc”, tak jak Sienkiewicz Trylogię (1883-1888), który łączył tradycję Scotta i Dumasa z polskim patriotyzmem.

W tym sensie powieść jest przekaźnikiem idei historiozoficznych, również z etnografią związanych, autora Lenina (1930) i odnosi się do problemu odzyskania przez Polskę Niepodległości w 1918 roku.

Haykowski Kresy „miał we krwi”». Jeśli chodzi o omawianą powieść, to zainteresował się nią również z tego względu, iż szereg miejscowości, które wymienia i o których pisze Ossendowski, były mu bliskie jako ułanowi (np. Krechowce, Jazłowiec, Żółkiew, Stanisławów). Ułani krechowieccy płk. Bolesława Mościckiego w Stanisławowie rzucili straszny siew śmierci na rozbestwione tlumy rosyjskiej dziczy żołdackiej. Z kolei 24 lipca 1917 roku pułk wsławił się szarżą na rosyjskie, niemieckie i austriackie wojska w Krechowcach pod Stanisławowem ${ }^{9}$. Po 1918 roku Polska uczyniła Stanisławów stolicą jednego z najważniejszych województw. Obecność Haykowskiego w 6. Pułku Strzelców Konnych im. Hetmana Wielkiego Koronnego Stanisława Żółkiewskiego należy kojarzyć z faktem, że Pułk stacjonował w Żółkwi, miejscowości należącej do bohatera spod Kłuszyna i Cecory.

Trzecią przyczynę należałoby wiązać z epoką historyczną, czasem wojen polsko-tureckich i polsko-tatarskich. Haykowski jako malarz batalista był świetnie przygotowany do oddania ducha tej epoki. Dał temu dowód w szeregu rysunków i obrazów ${ }^{10}$.

Odnosząc się do historiozofii Ossendowskiego, przybliżę najpierw kilka kwestii wiążących się z planem geograficznym i etnograficznym powieści. Zasiedlanie Karpat Wschodnich i terenów wysuniętych na wschód od Lwowa (Ruś Halicka) rozpoczęło się formalnie od 1364 roku za panowania króla Kazimierza Wielkiego. Osiedlała się tutaj drobna szlachta, także zbiegli chłopi i pasterze wołoscy (od XIV do XVII wieku). Wpływ na rozwój gospodarczy tych ziem miały rody Koniecpolskich, Potockich, Ossolińskich ${ }^{11}$. Ossendowski jako pisarz, historyk i etnograf jednocześnie, tworzy klimat epoki, przywołuje określone dane, wykorzystując swą książkę pt. Huculszczyzna. Gorgany i Czarnohora ${ }^{12}$, w której stwierdza m.in., że za Kazimierza Wielkiego Polska odziedziczyła całe Pokucie i Huculszczyznę i władała nimi przez cztery wieki, aby utracić je w 1772 roku (zabór austriacki) i odzyskać w 1918 roku. Zwraca uwagę na udział Hucułów w walkach z rosyjską armią, która na jesieni 1914 roku zajęła Małopolskę Wschodnią. Drogę przegrodziło jej

7 OSTROWSKI, Witold: Powieś́ historyczna. W: Słownik rodzajów i gatunków literackich. Red. G. Gazda - Sł. Makowska-Tynecka. Kraków: Universitas, 2006, s. 568-571.

8 Był synem Rajmunda Chajkowskiego (1856-1923), związanego z Podolem, ściślej z Mohylewem Podolskim do 1908 roku. W 1908 roku Rajmund Chajkowski osiadł wraz z rodziną w Klonowcu, koło Brwinowa pod Warszawą. Por. GORCZYCA, Wojciech: Stanistaw Haykowski... Op. cit., s. 5-23.

9 WRZOSEK, Mieczysław: Polskie formacje wojskowe w Rosji w latach 1917-1920. Niepodległość i Pamięć, 11, 1998.

10 Por. np. jego rysunki: Rotmistrz, W polskiej stużbie... Kozacy nadworni i Tatar Lipek. W: Księga Jazdy Polskiej. Op. cit., s. 73-74; GORCZYCA, Wojciech: Stanistaw Haykowski... Op. cit., s. 15-16.

11 JECDRYSIAK, Tadeusz - WYSZKOWSKA, Izabela: Turystyka kulturowa. W: Turystyka Kulturowa - portal popularyzacyjny, http:/ / turystykakulturowa.eu/wp.

12 OSSENDOWSKI, Ferdynand: Huculszczyzna. Gorgany i Czarnohora. Poznań: R. Wegner, 1936. Cyt. za: https://pl.wikisource.org/wiki/Huculszczyzna:_Gorgany_i_Czarnohora. 
młode wojsko polskie, z którego uformowano polską drugą brygadę „Legionów” noszącą nazwę „karpackiej” lub „żelaznej”. Ochotnicza kompania Hucułów dowodzonych przez kapitana Szeranca, chlubnie zapisała się na stronicach wojny w Karpatach ${ }^{13}$. Kilka istotnych dat wprowadzonych przez Ossendowskiego oraz wyeksponowanie relacji Polacy - Huculi, jeśli chodzi o udział w walkach z Rosjanami w Karpatach Wschodnich, pozwala twierdzić, iż pisarz uznaje etniczność za istotną kategorię, którą odnosi do poziomu mediatyzującego pomiędzy porządkiem lokalnym (mieszkańcy Karpat Wschodnich) i globalnym (naród). Pojmowanie tożsamości zbiorowej - etnicznej i narodowej - jako konstruktu społecznego łączy się z przyznaniem kluczowej roli dyskursom tożsamości. W ten sposób dyskurs literacki ma swą lokalizację społeczną, specyficzne cele, ograniczenia i właściwy sobie tryb kategoryzacji ${ }^{14}$.

Cele Ossendowskiego są dwa. W ewokowaniu czasu historycznego powieści chodzi mu przede wszystkim o podkreślenie, że tożsamość zbiorowa (etniczna i narodowa) jest tożsamością szlachecką. Od Sienkiewicza różni się tym, że dyskurs tożsamościowy odnosi przede wszystkim do szlachty bezherbowej.

Sposób ewokowania czasu historycznego w powieści to trzecia przyczyna zainteresowań Haykowskiego. Szlachcicem bezherbowym jest główny bohater powieści, rotmistrz łanowy, Jerzy Berezowski ${ }^{15}$ z Berezowa Wyżnego. Jego ukochana, Anielka Kolankowska, z Nadwornej na Pokuciu pochodzi ze szlachty zaściankowej ${ }^{16}$. Ossendowski realizuje jednocześnie drugi cel. Otwiera drzwi do teraźniejszości (lata 30. XX wieku) i tworzy perspektywę przyszłości. Interesują go ludzie o wielkim poczuciu obowiązku, ludzie szlachetni - „sól tej ziemi”. Z jednej strony eksponuje ich przynależność do obozu lokalnego, zakreślając geograficznie granice ich funkcjonowania (Pokucie, Wierchowina, zamek na Skale, zamek w Pniowie, Berezowo Wyżne, Nadworna, Kołomyja) i wskazuje na sąsiedztwo z wrogiem, jakim byli Tatarzy i Turcy (pole cecorskie, Jassy), z drugiej, do obozu globalnego, którego symbolizacją jest obóz w Żurawnie. Broni go król Jan III Sobieski ze swoim wojskiem. Jest to czas wojen polsko-tureckich i polsko-tatarskich w XVII wieku.

Z początkiem 1676 roku król Jan III Sobieski dysponował 30-tysięczną armią. Niebawem nastapił nowy atak armii turecko-tatarskiej dowodzonej przez Ibrahima Paszę, a po jego śmierci przez Ibrahima Szejtana. Prowadząc działania opóźniające, Sobieski wycofał się pod Żurawno nad Dniestr, gdzie zamknął się w obozie warownym. Wytrzymał dość długie oblężenie przez główne siły tureckie. Rozejm podpisano 17 października

13 Ibidem.

14 PROKOP-JANIEC, Elżbieta: Etniczność. W: Kulturowa teoria literatury. Główne pojęcia i problemy. Red. M. P. Markowski - R. Nycz. Kraków: Universitas, 2006, s. 419.

15 Berezów Wyżny był prywatną wsią szlachecką prawa wołoskiego, położoną w ziemi halickiej woj. ruskiego. Por.; Kasper Niesiecki w swym Herbarzu łączy ród Berezowskich z ziemią halicką, np. Paweł Berezowski około 1776 roku był pisarzem grodzkim Winnickim, natomiast Wojciech Berezowski horodniczym Bracławskim (1712 r.). Por. Kasper Niesiecki, Herbarz Polski, wyd. J.N. Bobrowicz, Lipsk 1839-1845 (t. 2 , s. 1006-1007) https://wielcy.pl>niesiecki.

16 Por. informacje na temat tego rodu: Ludwik Kolankowski - Kurier galicyjski https://kuriergalicyjski. com/historia/postacie/101-k/5809-ludwik-kolankowski. 
1676 roku. Utrzymywał on ciężkie dla Rzeczypospolitej straty terytorialne na rzecz Turcji, natomiast nie zawierał obowiązku płacenia haraczu ${ }^{17}$.

Rotmistrz Berezowski, podobnie jak jego druh, strażnik wojskowy, pan Zbrożek, „pit piotun z octem" ${ }^{18}$. Jako rotmistrz musiał organizować szkolenie swoich żołnierzy, dowodzić i walczyć, będąc zakochanym w Anielce Kolankowskiej, z którą zamierzał wziąć ślub. Plany pokrzyżował mu najazd Tatarów i uprowadzenie Anielki w jasyr. Od tego momentu bohater, który dowodził pod Batohem i w podhajeckim obozie ${ }^{19}$, działa „na dwa fronty”. Walczy i planuje odzyskanie Anielki. Pomaga mu w tym pan Zbrożek, strażnik wojskowy i jednocześnie słynny zagończyk, który chce wystawić rotmistrza Berezowskiego na samo czoło obrony Pokucia i Wierchowiny, żeby czambuły nie okrążyły Stanisławowa. Dał mu w tym celu dwie choragwie dragońskie i ze swego wojska dwa pułki kozackie. Resztę wojska miał rotmistrz Berezowski zorganizować sam. W krótkim czasie zwołał 50 rodów wszystkich gniazd Wierchowiny i Pokucia. Przybyli szlachcice z 24 miejscowości. Wszystkich poddał odpowiedniemu szkoleniu. Ze szlachty wierchowińskiej stworzył rotmistrz choragiew: „[...] to zbiorowisko ludzi wolnych, żadnej wtadzy nad soba nie majacej, w oka mgnieniu stawato sie wojskiem karnym, niebywale szybkim w ruchach i sprawnym"20.

Rotmistrz Berezowski, mimo odnoszonych nad Tatarami zwycięstw (np. pod Kołomyją, gdzie o zwycięstwie zadecydowała choragiew wierchowińska, zwana „krzyżakami”, wypuszczona w bój przez pana Zbrożka), ciągle „pił piołun z octem”. Cierpienie psychiczne bohatera, spowodowane uprowadzeniem ukochanej w jasyr, zostaje częściowo rozładowane w Mołotkowie. U państwa Gnoińskich rotmistrz spotyka księdza, który namawia go do wspólnej modlitwy. Ten fragment powieści Ossendowskiego specjalnie zainteresował Stanisława Haykowskiego. Wyobrażenie modlitwy jest rysunkiem wyjątkowym w całej twórczości tego malarza batalisty.

17 Por. PODRAZA, Antoni: Europa w XVII wieku. W: Wielka historia świata. Świat w XVII wieku. T. 7. Red. A. Podraza. Warszawa: „Świat Książki”, 2006, s. 516. 18 października 1672 roku doszło do zawarcia traktatu w obozie sułtańskim pod Buczaczem (wcześniej, 2 października 1672 roku Turcy zdobyli Kamieniec Podolski. Zginął wówczas Jerzy Wołodyjowski, stolnik przemyski, komendant chorągwi jazdy - prototyp postaci Michała Wołodyjowskiego z powieści Henryka Sienkiewicza Pan Wołodyjowski). Warunki podyktowane przez Turków pod Buczaczem były bardzo twarde. Polska utraciła województwa: podolskie, kijowskie i bracławskie, a przy tym stawała się lennikiem tureckim płacącym 22 tys. dukatów rocznego haraczu, zwanego upominkiem.

18 'Piołun' - w znaczeniu: Życie pełne piołunu, zaprawione piołunem, por. Stownik wspótczesnego języka polskiego. Red. B. Dunaj. Warszawa: Wydawnictwo WILGA, 1996, s. 749.

19 20. 5. 1652 roku doszło do bitwy pod Batohem między wojskami polskimi i kozacko-tatarskimi. Bitwa zakończyła się całkowitym pogromem Polaków. Zginął w niej kwiat młodzieży szlacheckiej, m.in. Marek Sobieski, brat przyszłego króla. Por. op. cit., s. 447, 481. „Pomyłka” Ossendowskiego przydaje głównemu bohaterowi splendoru. Podkreśla jego zasługi dla Polski. W powieści Pod sztandarami Sobieskiego rotmistrz Berezowski ma 33 lata. Skoro oblężenie obozu pod Żurawnem miało miejsce w 1676 roku, to w 1652 roku, jako 9-letni chłopiec nie mógł walczyć pod Batohem. Wiarygodny jest natomiast, ,jako fakt literacki”, udział Berezowskiego w powstrzymaniu przez Jana Sobieskiego pod Pohajcami (jesień 1667 r.) armii kozacko-tatarskiej maszerującej na Lwów.

20 OSSENDOWSKI, Ferdynad: Pod sztandarami Sobieskiego. Warszawa: Wydawnictwo „Pobudka”, 1930. https://pl.wikisource.org/wiki/Pod_sztandarami_Sobieskiego. 
„Prawie ciemno byto w izbie, gdyz tylko przed krucyfiksem wiszacym na ścianie petgato mate światetko w lampce oliwnej.

- Uklęknij, synu, przed Ukrzyżowanym i powiedz mu wszystko, co brzemieniem cięzkim leży ci na sercu... - szepnąt ksiadz i opuściwszy się na kolana, ręce wyciagnąt do Krzyża Męki, szepczac stowa modlitwy tacińskiej.

Nie wiadomo jak się to stato, lecz pan Jerzy poczat się żalić przed Zbawicielem na ból swego serca, na strach o umitowana dziewczyne, na troskę swoja $i$ udręke gryzaca.

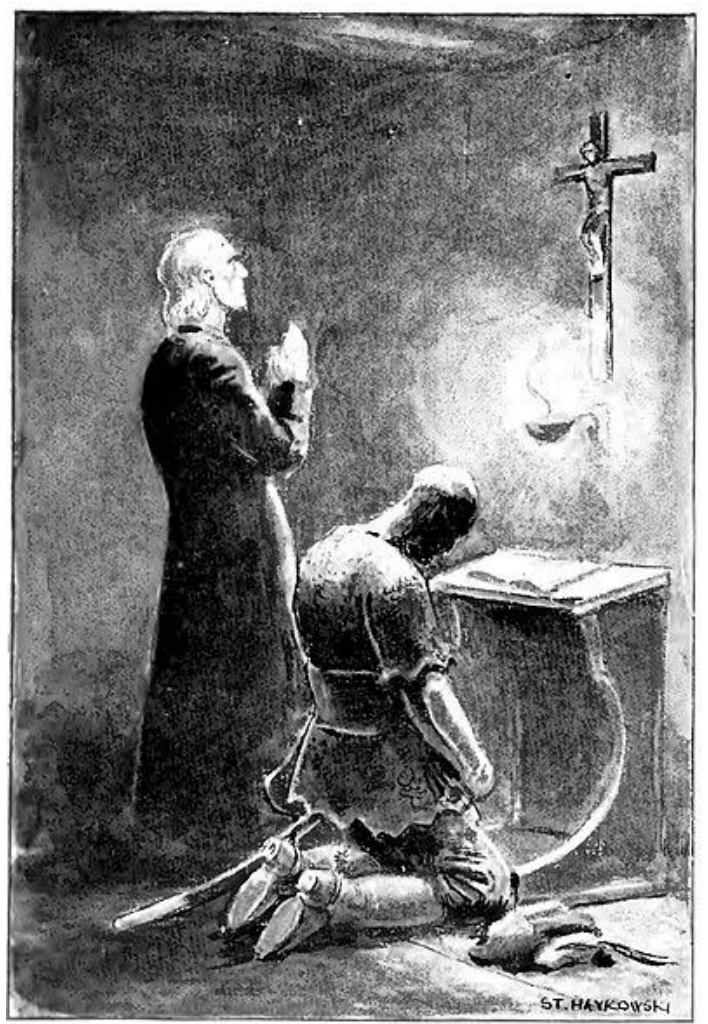

„Chryste... Synu Boży - szeptat...”

- Chryste... Synu Boży - szeptat - oto serce moje żotnierskie raduje sie zwycięstwem, które ojczyźnie na zdrowie wypadnie $i$ na chwate, ale niech ino ochtonę krztyne, a już wyje mi coś w duszy: „ty się radujesz, a ona tam u bisurmanów w jasyrze, branka bezbronna, może już nie żywie, a może pohańbiona..." Rotmistrz czotem upadt na ziemię $i$ korzyt sie przed umęconym Chrystusem, dyszac cięzko i gwattownie, bo z wielkiego wzruszenia tchu ztapać nie mógt. "21

Haykowski sięga do tradycji Rembrandta, jeśli chodzi o grę światła, cienia i półcienia. Wprowadza pełną symbolizację etosu rycerskiego. Kategoria światła, cienia i półcienia,

21 OSSENDOWSKI, Ferdynand: Pod sztandarami ... Op. cit. 
będąc metaforą, staje się narzędziem budowania świata. Gaston Bachelard twierdzi, że światło jest wręcz utożsamiane ze światem, na przykład dla człowieka samotnego płomień jest światem ${ }^{22}$. Tak jest właśnie na rysunku Haykowskiego. Płomień lampki oliwnej, w przeciwieństwie do wyobrażonego przez Ossendowskiego, ma dużą moc. Pokonuje drogę od twarzy księdza, złożonych pionowo w modlitwie jego dłoni, modlitewnika rozłożonego na klęczniku i tyłu głowy rotmistrza Berezowskiego do jego barków, odzianych w kolczugę, przedramienia, od dołu przykrytego sztywną płytą (pozostałość po zbroi płytowej) oraz prawej łydki i końca pochwy szabli.

Na rysunku Haykowskiego mamy do czynienia z metafora umysłu ${ }^{23}$. Rysownik rzuca światło na postrzegane przez siebie części ciała i przedmioty, niejako je współtworząc. Cierpienie rotmistrza odkrywa ciało - przede wszystkim pochylona głowa. Jednocześnie oświetlone barki i przedramię nie symbolizują całkowitego załamania duchowego.

Scena modlitwy, wykreowana przez Haykowskiego, różni się nie tylko w szczegółach od tego, co przedstawił Ossendowski. Przede wszystkim u Haykowskiego klęczy rotmistrz, a ksiądz stoi. Niewątpliwie przyjęta postawa wertykalna i dokładnie pionowo złożone w modlitwie ręce księdza w obfitym świetle lampki oliwnej zaświadczają o jego „zwierzchnictwie”, przywileju pierwszej prośby, pierwszego błagania. U Ossendowskiego ksiądz dodatkowo wykonuje ruch sakralny - wyciaga ręce do krzyża i szepce słowa modlitwy łacińskiej (łacina, jak twierdzą hierarchowie Kościoła, to język aniołów). Haykowski pominął tego rodzaju rozwiązanie.

Podobnie, pominął, można rzec, że odrzucił, finalne, kreślone nieco pompatycznie, zachowanie modlącego się bohatera - 33-letniego, a więc będącego w tzw. „wieku Chrystusowym” rotmistrza Jerzego Berezowskiego: „Rotmistrz czotem upadt na ziemię i korzyt sie przed umęzonym Chrystusem, dyszac cięzko i gwattownie, bo z wielkiego wzruszenia tchu ztapać nie mógt". Stanisław Haykowski jest mistrzem aktorstwa ciała - ciała rycerza. Maurice Mearleau-Ponty podkreślał zaangażowanie ciała we wszystkie struktury typowe świata.

Pokazać, jak widzimy, to także zinterpretować tekst literacki. Światło w interpretacji Haykowskiego można nazwać agonalnym, tj. związanym z metaforą pojęcia agonu, rozumienia, przyjętego jako spór, gra głosów ${ }^{24}$. W ten sposób metafora światła jest u Haykowskiego związana z metafora "wiązki światła” i współtworzącą ją metaforą "wiązki odczytań”. Najlepiej rysunek Haykowskiego z wybranym przez niego cytatem („Chryste... Synu Boży - szeptat...”) odczytywać jako grę głosów, która mieści się w relacji „światła rzuconego" do „światła odebranego".

Finał wojennych sukcesów rotmistrza Berezowskiego ma miejsce pod obozem w Żurawnem, którego broni król Jan III Sobieski. Dochodzi tutaj do kilku „wycieczek”, krótkich spięć i małych bitew z Tatarami, w których bierze udział rotmistrz ze swoją chorągwią złożoną ze szlachty wierchowińskiej. Po jednej z takich bitew Jan III Sobieski pyta pana Zbrożka, która to z jego choragiwi tak dzielnie stawała. Strażnik wojskowy odpowiada, że nie była to jego choragiew, lecz choragiew rotmistrza Berezowskiego.

22 BACHELARD, Gaston: Ptomień świecy. Przeł. J. Rogoziński. Gdańsk: słowo/obraz/terytoria, 1996, s. 10.

23 KRAJEWSKA, Anna: Światto jako metafora epistemologiczna. W: Literatura i Wiedza. T. 87. Red. Władysław Bolecki - Elżbieta Dąbrowska. Warszawa: IBL, 2006, s. 172-176. 
Po bitwie król wyraził szczery podziw dla dokonań wierchowińców i wydał polecenie, aby rotmistrz Berezowski wraz z panem Zbrożkiem zameldował się nazajutrz po mszy w jego namiocie. Ten fragment powieści Ossendowskiego zainteresował Haykowskiego jako malarza batalistycznego, który tworzy ilustrację interpretacyjną, ekspresywną.

"- Widziatem takoż jakowąs choragiew twoja, która na tytach zgniotta Tatarów! - powiedziat z uśmiechem. - Jakaż to byta? Po nocy ino niby cienie od mroku czarniejsze w oczach mi migotata! - Choragiew z Wierchowiny, szlachta zagrodowa z Czarnohory i Beskidu, Wasza Królewska Mość. Prowadzit ja rotmistrz Jerzy Berezowski.

- Hę? To oni wtaśnie?! - ucieszyt się król. - Pragnątbym w oczy dziś jeszcze zajrzeć tym „wilkotakom” okrutnym.

$[\ldots]$

- Widziatem robote waszmościów wczoraj wieczorem - mówit, objeżḋając szeregi „krzyżaków” - $i$ podziwiatem, zaiste - podziwiatem! Ze szczerego serca dziękuje waszmościom, panowie szlachta, mili rycerze z Czarnohory, Czywczynu, Beskidu i wysokich potonin zielonych! Na wspomnienie króla $i$ umitowanego wodza o ich rodzinnym kraju, o którym snadź Sobieski dobrze wiedziat, Wierchowińcy poczelli wiwatować na cześć swojego pana [...].

Król tymczasem zwrócit się do stojacego bokiem do choragwi rotmistrza i powiedziat:

- A waść jutro po mszy, jeżeli spokój mieć będziemy, wraz z panem strażnikiem wojskowym zameldujesz sie w moim namiocie!" 25

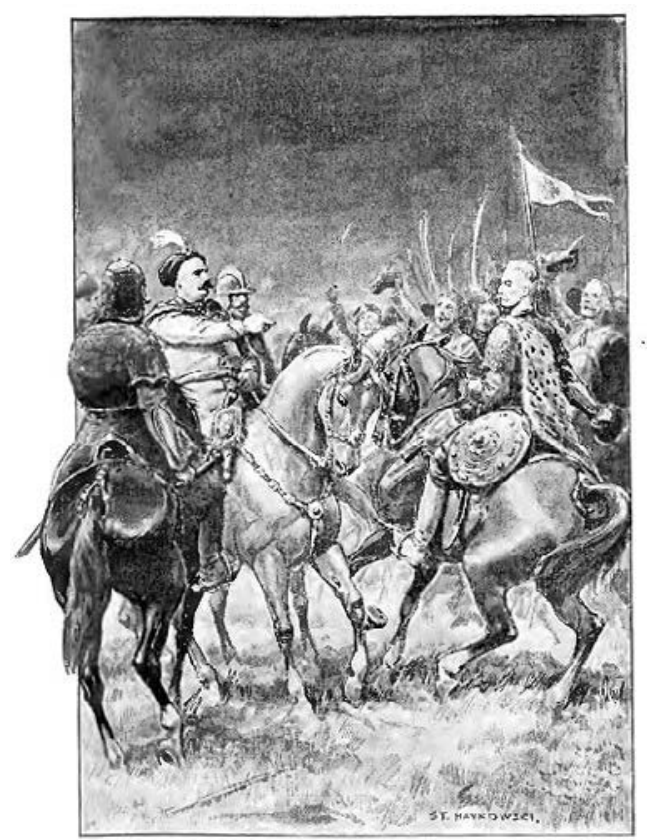

Król tymczasem zwrócit się do rotmistrza...

25 OSSENDOWSKI, Ferdynand: Pod sztandarami... Op. cit. 
Jak widać, Haykowski wprowadza na scenę zdarzenia trzecią postać (obok króla i rotmistrza). Jest to niewątpliwie pan strażnik koronny. Zad karego konia pana Zbrożka, fragment szabli oraz niewielką część jego tułowia sytuuje Haykowski poza ramą obrazu. Rysownik zdaje się postępować zgodnie z maksymą starożytnych: [...] znak jest czymś znanym, co dostarcza informacji o czymś niejawnym (chwilowo lub trwale) ${ }^{26}$. Co może być niejawne na tym rysunku? Odpowiedź wiąże się z przywołaniem określonych informacji dotyczących funkcji parergonu (para - poza; ergon - dzieło) ${ }^{27}$. Jak pisze Jaques Derrida, parergon nie może być utożsamiany z tym, „co jedynie otacza dzieło”. Nie będąc ani dziełem (ergon), ani poza dziełem, ani wewnątrz, ani zewnątrz; ani ponad, ani pod nim, parergon dezorganizuje wszelkie opozycje, sam nie pozostaje nieokreślony i daje początek dzielu ${ }^{28}$.

W wypadku rysunku Haykowskiego, jeśli chodzi o pojęcie parergonu, mamy do czynienia z tzw. „przekraczaniem bariery”, tj. przekroczeniem granicy między przedstawieniem a widzem. Jaki zatem „początek” swego dzieła tworzy Haykowski?

„Początek” wiąże się z postacią pana Zbrożka, który „przesuwa” konia w lewo, aby bardziej odkryć postać króla. Jednocześnie skręt ciała rycerza w prawo pozwala mu spojrzeć w kierunku choraggwi wierchowińskiej - przede wszystkim zaś w kierunku jego druha, rotmistrza Berezowskiego. Zbrożek nie patrzy specjalnie na króla. Dodaje to pewności rotmistrzowi, który prezentuje się godnie.

Dyskurs artystyczny Haykowskiego na tym rysunku, jeśli chodzi o problem tożsamościowy, jest bardziej wiarygodny aniżeli tożsamościowy dyskurs literacki Ossendowskiego. Strażnik wojskowy, pan Zbrożek (reprezentujący obóz globalny) jest bezpośrednim sprawca połączenia obozu lokalnego, który reprezentuje rotmistrz Berezowski, z globalnym. Łączą się tutaj umiejętności dowodzenia tych rycerzy, ich przyjaźń oraz trudna sytuacja osobista („piją piołun z octem”). Król podkreślił tożsamość, mówiąc „poetycko” o Czarnohorze i wysokich połoninach zielonych. O dziele strażnika wojskowego, pana Zbrożka, słynnego zagończyka, „publicznie” nie wspomniał. Globalny dyskurs tożsamościowy, który Ossendowski szczególnie wyeksponował, w komplementach króla skierowanych do Wierchowińców, Haykowski zniwelował, eksponując indywidualny dyskurs tożsamościowy, którego bohaterami są pan Zbrożek i rotmistrz Berezowski jako rycerze i przyjaciele. Tym samym uniknął stanowiska, w którym mogłoby pojawić się myślenie utopijne. Jest ono charakterystyczne dla Ossendowskiego i wiąże się z uwzględnieniem relacji: fakt - fikcja ${ }^{29}$. Powstającą i umacniającą się w powieści tożsamość globalną odnosi Ossendowski w szczególny sposób do historii walk Polski z Turcją i Tatarami, eksponując nasze

26 Por. uwagi na ten temat: BUCZYŃSKA-Garewicz, Hanna: Semantyka Peirce'a. Warszawa: ZSL UW, 1994, s. 20-25.; KOJ, Leszek: Próba zdarzeniowej teorii znaku. W: O nauce i filozofii nauki. Księga poświęcona pamięci Jerzego Giedymina. Red. K. Zamiara. Poznań: Wydawnictwo Fundacji Humaniora, 1995, s. 57-78.

27 STRONCIWILK, Agata: Miedzyprzestrzenie. Rama, obramowanie i passe-partout. W: http://www.anthropos. us.edu.pl/anthropos14/texty/stronciwilk.htm.

28 Ibidem.

29 Por. KIEREŚ, Henryk: Cztowiek i cywilizacja. Lublin: Instytut Edukacji Narodowej, 2007, s. 154-155. Cyt. za: GORCZYCA, Wojciech: Wschodni utopizm Wtodzimierza Sotowiowa i symbolistów rosyjskich. W: Problemy utopii i antyutopii w literaturach słowiańskich i historii Słowian. Red. Wojciech Gorczyca - Ivo Pospíšil. Bielsko-Biała: Wydawnictwo Naukowe Akademii Techniczno-Humanistycznej, 2014, s. 167-168. 
zwycięstwa i sukcesy. Niektóre z nich, jeśli chodzi o odzyskiwanie terytoriów, jak np. zwycięstwo pod Żurawnem, nie miały większego znaczenia ${ }^{30}$. Przyjęty rodzaj historiozofii pisarza, zmierzający do otwarcia drzwi do teraźniejszości i projektujący przyszłość przejawia się w takiej interpretacji „faktu literackiego”, który ma możliwość prefigurowania historii pod kątem przyznawania jej wartości „naddanych” - nie tylko historii zresztą również religii. Przykładem takiego postępowania Ossendowskiego jest odnawianie znaczenia Kołomyi, miasta założonego przez Kazimierza Wielkiego (1366-1370) na prawie magdeburskim. Kołomyja w XV wieku była miejscem sądu grodzkiego, a w XVI sądu ziemskiego. Tutaj hospodar wołoski Stefan III Wielki złożył w 1459 roku hołd królowi Kazimierzowi Jagiellończykowi. Tutaj wreszcie, w 1915 roku, w Kołomyi została powołana słynna II Brygada Legionów, nazwana Żelazną lub Karpacką. W Brygadzie tej walczyły dwa szwadrony rotmistrza Zbigniewa Dunina-Wąsowicza. Jeden ze szwadronów wziął udział w słynnej szarży pod Rokitną (13 czerwca 1915 r.), co uwidocznił na swoim obrazie Stanisław Haykowski (Szarża pod Rokitna - 1934) ${ }^{31}$. W latach 1919-1939 Kołomyja była miastem powiatowym, największym w województwie stanisławowskim ${ }^{32}$.

19. 3. 1931 roku delegacja Hucułów z okolic Kołomyi podarowała Józefowi Piłsudskiemu z okazji jego urodzin miecz huculski z klingą o długości $97 \mathrm{~cm}^{33}$.

Kołomyja współtworzy w powieści Ossendowskiego kilka „faktów literackich”. Najważniejszy to taki, że w kościele w Kołomyi bierze ślub z kruczowłosa Anielką Kolankowska rotmistrz Berezowski. Odzyskał ją wcześniej z rąk Tatarów dzięki zwycięstwu Jana III Sobieskiego pod Żurawnem. Pomógł mu w tym wydatnie pan Zbrożek, który zaopatrzył go w odpowiednie listy i pieczęcie tureckie, kiedy rotmistrz wyjeżdżał do Jass po Anielkę. Zwycięstwo spowodowało również, jak chce Ossendowski, że Polska odzyskała utracone ziemie.

„Zniechęcony (Ibrahim Szejtan - uzup. W.G.), przerażony cięzkimi stratami w ortach janczarskich i wieściami o zbliżajacych się od Lwowa positkach dla Sobieskiego, jak też wynikajacymi coraz czéściej gwattownymi sporami z Selim Girejem, nie zamierzat upierać się dtużej przy artykutach traktatu buczackiego $[\ldots]$

$[\ldots]$

W dniu 14 października [...] Ibrahim Szejtan w imieniu sultana podpisat traktat, wedtug którego Turcja zwracata Polsce ziemie po Biata Cerkiew i Pawotocz i oddawata zagarnięty jasyr w ilości 12.000 ludzi, mężczyzn, kobiet i dzieci [...]."34

30 Rozejm, zawarty w wyniku przeprowadzonych pod Żurawnem rokowań między stroną polską i turecką (17.X. 1676 r.) utrzymywał uciążliwe dla Rzeczypospolitej straty terytorialne na rzecz Turcji (Podole z Kamieńcem Podolskim, znaczna część Ukrainy prawobrzeżnej, natomiast nie zawierał obowiązku płacenia haraczu. Por. PODRAZA, Antoni. Op. cit., s. 516).

31 O tym szerzej: GORCZYCA, Wojciech: Stanistaw Haykowski... Op. cit., s. 67-80.

32 Kołomyja - Wikipedia https://pl.wikipedia.org/wiki/Kołomyja.

33 http://www.muzeumwp.pl/emwpaedia/miecz-huculski-dar-huculow-dla-marszalka-jozefa-pilsudskiego. php.

34 OSSENDOWSKI, Ferdynand: Pod sztandarami... Op. cit. 
Podobnie optymistycznych informacji, co w cytowanych wyżej stwierdzeniach Ferdynanda Ossendowskiego, u Antoniego Podrazy na temat rozejmu związanego z obrona obozu pod Żurawnem nie znajdujemy. Ustalenia Ossendowskiego mają tylko niewielki związek z danymi historycznymi - w dodatku wykluczają się. Z decyzji Ibrahima Szejtana, występującego w imieniu sułtana tureckiego, wynika, że postanowienia traktatu buczackiego sa już dla niego nieaktualne, tj. Polska powinna odzyskać wszystkie utracone ziemie. Tymczasem Polska w wyniku podpisanego rozejmu odzyskała tylko niewielką część ziem - bez Kamieńca Podolskiego i Podola (w tym województwa bracławskiego). Można rzec, że Ossendowski otworzył drzwi do teraźniejszości zbyt szeroko.

\section{Bibliografia}

\section{Teksty źródłowe}

OSSENDOWSKI, Ferdynand. Huculszczyzna. Gorgany i Czarnohora. Poznań (R. Wegner), 1936. https://pl.wikisource.org/wiki/Huculszczyzna:_Gorgany_i_Czarnohora.

OSSENDOWSKI, Ferdynad. Pod sztandarami Sobieskiego. Warszawa: Wydawnictwo „Pobudka”, 1930.

\section{Artykuły, monografie}

BACHELARD, Gaston: Ptomień świecy. Przeł. J. Rogoziński. Gdańsk: słowo/obraz/terytoria, 1996. BARTOSZEWSKI, Władysław: Straceni na ulicach miasta. Warszawa: Książka i Wiedza, 1970.

Berezów Wyżny. https://pl.wikipedia.org/wiki/Berez\%C3\%B3w_Wy\%C5\%BCny.

BUCZYŃSKA-Garewicz, Hanna: Semantyka Peirce'a. Warszawa: ZSL UW, 1994.

GORCZYCA, Wojciech: Stanistaw Haykowski (1902-1943). Utan i malarz batalista. Bielsko-Biała: Wydawnictwo Naukowe Akademii Techniczno-Humanistycznej, 2018.

GORCZYCA, Wojciech: Wschodni utopizm Wtodzimierza Sotowiowa i symbolistów rosyjskich. W: Problemy utopii i antyutopii w literaturach słowiańskich i historii Słowian. Red. W. Gorczyca - I. Pospísil. Bielsko-Biała: Wydawnictwo Naukowe Akademii Techniczno-Humanistycznej, 2014.

JĘDRYSIAK, Tadeusz - WYSZKOWSKA, Izabela: Turystyka kulturowa. W: portal popularyzacyjny

- Turystyka Kulturowa, http://turystykakulturowa.eu/wp.

KIEREŚ, Henryk: Cztowiek i cywilizacja. Lublin: Instytut Edukacji Narodowej, 2007.

KOJ, Leszek: Próba zdarzeniowej teorii znaku. W: O nauce i filozofii nauki. Księga poświęcona pamięci Jerzego Giedymina. Red. K. Zamiara. Poznań: Wydawnictwo Fundacji Humaniora, 1995.

Kołomyja - Wikipedia, https://pl.wikipedia.org/wiki/Kołomyja.

KRAJEWSKA, Anna: Światto jako metafora epistemologiczna. W: Literatura i Wiedza. T. 87. Red. Wł.

Bolecki i Elżb. Dąbrowska. Warszawa: IBL, 2006.

Ksiega Jazdy Polskiej. Kierownictwo i opracowanie Stanisław Haykowski Warszawa, 1937.

Ludwik Kolankowski - Kurier galicyjski https://kuriergalicyjski.com/historia/postacie/101-k/ 5809-ludwik-kolankowski. 
Miecz huculski - http://www.muzeumwp.pl/emwpaedia/miecz-huculski-dar-huculow-dla-marszalka-jozefa-pilsudskiego.php.

NIESIECKI, Kasper: Herbarz Polski. Wyd. J.N. Bobrowicz, Lipsk 1839-1845 (t. 2, s. 1006-1007), https://wielcy.pl/niesiecki.

OSTROWSKI, Witold: Powieść historyczna. W: Stownik rodzajów i gatunków literackich. Red. G. Gazda - Sł. Makowska-Tynecka. Kraków: Universitas, 2006.

PROKOP-JANIEC, Elżbieta: Etniczność. W: Kulturowa teoria literatury. Główne pojęcia i problemy. Red. M. P. Markowski - R. Nycz. Kraków: Universitas, 2006.

RUTKIEWICZ, Ewa: Wokót problemów ilustracji. http://www.ebib.pl/2010/118/a.php?rutkiewicz.

STRONCIWILK, Agata: Międzyprzestrzenie. Rama, obramowanie i passe-partout. W: http://www. anthropos.us.edu.pl/anthropos14/texty/stronciwilk.htm.

WRZOSEK, Mieczysław: Polskie formacje wojskowe w Rosji w latach 1917-1920. Niepodległość i Pamięć, 11, 1998.

Wojciech Gorczyca, profesor emeritus

ul. Bratnia 35B, 43-354 Czaniec, PL

wgorczyca@ath.bielsko.pl

wojtekgorczyca42@gmail.com 